\title{
EVALUASI RASIONALITAS PENGGUNAAN OBAT DIABETES MELITUS TIPE II PADA PASIEN RAWAT JALAN DI PUSKESMAS PASIR SAKTI TAHUN 2019
}

\author{
Evaluation Rationality Of Diabetes Melitus Type II Medicine \\ In Out Patiens At Pasir Sakti Public Health Center \\ In 2019
}

\author{
Dwi Aulia Ramdini', Lilik Koernia Wahidah², Dwi Atika \\ ${ }^{1}$ Fakultas Kedokteran Program Studi Farmasi Universitas Lampung \\ ${ }^{2}$ Program Studi Farmasi, Universitas Tulang Bawang Lampung \\ e-mail : dwi.aulia@fk.unila.ac.id \\ HP. 0857-9950-0086
}

\begin{abstract}
Diabetes mellitus is a metabolic disease characterized by hyperglycemia, due to abnormal insulin secretion, insulin action or both. Hyperglycemia is a condition in which blood glucose levels increase or exceed normal limits. This study aims to evaluate the treatment of type II diabetes mellitus in outpatients in Puskesmas Pasir Sakti. This research is a nonexperimental research with a descriptive design taken retrospectively. The sample in this study were all outpatients with a diagnosis of type II diabetes mellitus at Puskesmas Pasir Sakti 2019. The sampling technique used was Total sampling. The sample of this study is the medical record data of patients with type II diabetes mellitus in 2019 adjusted for inclusion criteria. Characteristics based on gender of patients with type II diabetes melitus there are 23 male patients that is $29 \%$ and 57 female patients that is $71 \%$. Characteristics based on the age of most patients in the Elderly (46-65 years) as many as 65 patients (81\%). cases of type II diabetes mellitus patients without complications were 39 patients (49\%) cases of type II diabetes mellitus patients with complications of 41 patients (51\%). The results of the rationality of antidiabetic use in outpatients at the Puskesmas Pasir Sakti in 2019 According to PERKENI 2015 obtained the use of drugs based on the exact parameters indicated as much as $97.5 \%$, the right drugs as much as $98.75 \%$, the right dosage as much as $100 \%$, the right way of administration as much as $100 \%$, the exact time interval of $100 \%$, and medication adherence of $100 \%$. Treatment of type II diabetes melitus who received rational therapy was $96,25 \%$ while irational therapy is $3,75 \%$.
\end{abstract}

Keywords: Diabetes Mellitus, Evaluation, Medicine, Rationality.

\begin{abstract}
Abstrak
Diabetes melitus merupakan penyakit metabolik dengan karakteristik hiperglikemia, karena kelainan sekresi insulin, kerja insulin atau keduanya. Hiperglikemia adalah suatu keadaan dimana kadar glukosa dalam darah meningkat atau melebihi batas normal. Penelitian ini bertujuan mengevaluasi pengobatan Diabetes Melitus tipe II pada pasien rawat jalan di Puskesmas Pasir Sakti. Penelitian ini merupakan suatu penelitian non eksperimental dengan rancangan deskriptif yang diambil secara retrospektif. Sampel dalam penelitian ini adalah seluruh pasien rawat jalan dengan diagnosa Diabetes Melitus tipe II di Puskesmas Pasir Sakti 2019. Teknik pengambilan sampel yang digunakan yaitu secara Total sampling.
\end{abstract}




\section{JFL \\ Jurnal Farmasi Lampung \\ Vol . 9 No. 1 Juni 2020}

Sampel penelitian ini adalah data rekam medik pasien diebetes melitus tipe II pada tahun 2019 yang disesuaikan kriteria inklusi. Karakteristik berdasarkan jenis kelamin pasien diabetes melitus tipe II terdapat 23 pasien lak-laki (29\%) dan 57 pasien perempuan (71\%). Karakteristik berdasarkan usia pasien terbanyak pada Lansia (46-65 tahun) sebanyak 65 pasien (81\%). kasus pasien Diabetes Melitus tipe II tanpa penyakit komplikasi sebanyak 39 pasien yaitu (49\%) kasus pasien Diabetes Melitus tipe II dengan penyakit komplikasi 41 pasien yaitu $(51 \%)$. Hasil rasionalitas penggunaan antidiabetik pada pasien rawat jalan di Puskesmas Pasir Sakti tahun 2019 Menurut PERKENI 2015 diperoleh penggunaan obat berdasarkan parameter tepat indikasi sebanyak $97,5 \%$, tepat obat sebanyak $98,75 \%$, tepat dosis sebanyak $100 \%$, tepat cara pemberian sebanyak $100 \%$, tepat interval waktu sebanyak $100 \%$, dan kepatuhan pengambilan obat sebanyak $100 \%$. Pengobatan diabetes melitus tipe II yang mendapatkan terapi rasional sebanyak $96,25 \%$ sedangkan untuk terapi tidak rasional sebanyak $3,75 \%$.

Kata Kunci : Diabetes Melitus, Evaluasi, Obat, Rasionalitas

\section{PENDAHULUAN}

Diabetes melitus (DM) didefinisikan sebagai penyakit kronis atau gangguan metabolisme karbohidrat, protein dan lemak akibat tidak cukupnya sekresi insulin pada jaringan. Diabetes melitus merupakan penyakit metabolik dengan karakteristik hiperglikemia, karena kelainan sekresi insulin, kerja insulin atau keduanya. Hiperglikemia adalah suatu keadaan dimana kadar glukosa dalam darah meningkat atau melebihi batas normal (1).

Menurut World Health Organization (WHO) kenaikan jumlah penyakit DM di Indonesia dari 8,4 juta pada tahun 2000 bertambah menjadi 21,3 juta pada tahun 2030. International Diabetes Federation (IDF) memprediksi bahwa pada tahun 2009-2014 adanya kenaikan jumlah penyakit DM dari 9,1 juta pada tahun 2014 menjadi 14,1 juta pada tahun 2035 (2). Berdasarkan Riset Kesehatan Dasar (RISKESDAS) tahun 2018 prevalensi penyakit DM, pada usia $\geq 15$ tahun di Indonesia mengalami peningkatan dari 1,5\% di tahun 2013 menjadi 2,0\% ditahun 2018. Provinsi DKI Jakarta menduduki urutan pertama dengan jumlah penderita terbanyak dan urutan kedua berada di Provinsi Bengkulu. Provinsi Lampung menduduki urutan ke-27 dari 34 Provinsi di Indonesia (3). Menurut Profil Dinas Kesehatan Provinsi Lampung tahun 2015 mencatat data 10 terbesar seluruh penyakit, diabetes melitus menduduki peringkat ke-8 di Lampung (4).

Penyakit DM tidak dapat menyebabkan kematian secara langsung, tetapi dapat berakibat fatal jika penggunaan terapinya tidak tepat. Ketidaktepatan terapi dapat menyebabkan kondisi pasien semakin memburuk dengan munculnya penyakit komplikasi, diantaranya komplikasi makrovaskular seperti penyakit jantung koroner, penyakit pembuluh darah otak, dan penyakit pembuluh darah perifer (1). Penyakit DM memerlukan perawatan medis jangka panjang agar dapat mengendalikan berbagai risiko multifaktor demi tercapainya terapi yang maksimal dalam pengontrolan kadar glukosa darah. Pentingnya perawatan untuk pasien DM adalah mencegah terjadinya komplikasi akut dan mengurangi resiko terjadinya komplikasi berkelanjutan, sehingga tidak membahayakan jiwa maupun kualitas hudup seseorang (5).

Tingginya angka kejadian DM serta pentingnya penanganan secara tepat mendorong dibutuhkannya pengobatan secara rasional. Saat ini rasionalitas penggunan obat masih menjadi masalah besar dalam dunia pengobatan. Rasionalitas pengobatan terdiri atas ketepatan terapi yang dipengaruhi proses diagnosis, pemilihan terapi, pemberian terapi, serta evaluasi terapi (6). 
Penggunaan obat yang rasional harus tepat dalam hal indikasi, tepat dosis, tepat obat dan tepat cara penggunaan serta lama penggunaan obat. Menurut $\mathrm{WHO}$ terdapat $50 \%$ lebih penggunaan obat tergolong tidak rasional dalam hal peresepan, penyiapan, ataupun penjualannya, $50 \%$ lainnya adalah penggunan yang tidak tepat oleh pasien (7).

Ketidakrasionalan penggunaa obat dapat menyebabkan meningkatnya biaya pengobatan. Dampak kerugian yang didapat bisa mencapai miliaran pertahunnya akibat terjadinya reaksi obat yang merugikan dan kesalahan pengobatan. Penggunaan obat yang rasional sangat penting untuk pasien agar tercapainya kualitas hidup dan kesejahteraan masyarakat yang lebih baik (9). Salah satu upaya untuk mencegah penggunaan obat tidak rasional adalah dengan melakukan evaluasi penggunaan obat. Kegiatan ini merupakan suatu proses jaminan mutu yang terstruktur dan dilakukan secara terus menerus untuk menjamin agar obat-obat yang digunakan tepat, aman dan efisien (7).

Berdasarkan uraian diatas, penelitian ini bertujuan untuk mengetahui pengobatan Diabetes melitus tipe II pada pasien rawat jalan di Puskesmas Pasir Sakti berdasarkan parameter tepat indikasi, tepat pemilihan obat, tepat dosis, tepat cara pemberian, tepat interval waktu, dan kepatuhan pengambilan obat.

\section{METODE PENELITIAN}

Penelitian ini dilakukan pada bulan Januari 2020 di Puskesmas Pasir Sakti kecamatan pasir sakti. Jenis Penelitian ini adalah non eksperimental dengan pendekatan deskriptif yang diambil secara retrospektif. Menggunakan rangcangan penelitian total sampling. Kemudian dianalisis berdasarkan karakteristik pasien (usia, jenis kelamin, diagnosis). Data yang diperoleh dianalisis secara deskriptif kualitatif, kemudian data ditabulasikan dan hasil penelitian dapat dikaji ketepatan berdasarkan kriteria 6T (Tepat indikasi, Tepat pemilihan obat, Tepat Dosis, Tepat cara pemberian, Tepat interval dan Kepatuhan pemilihan obat)

\section{Populasi dan Sampel Penelitian}

Populasi dalam penelitian ini adalah seluruh pasien rawat jalan diabetes melitus tipe II di Puskesmas Pasir Sakti tahun 2019.

\section{Variabel Penelitian}

Variabel bebas dalam penelitian ini yaitu meliputi rekam medik (usia, jenis kelamin, diagnosis) dan resep (penggunaan antidiabetik) Sedangkan variabel terikat dalam penelitian ini yaitu rasionalitas berdasarkan indikator 6T (Tepat indikasi, Tepat pemilihan Obat, Tepat Dosis, Tepat cara pemberian, tepat interval waktu dan kepatuhan pengambilan obat).

\section{Pengumpulan Data}

Data yang dikumpulkan dalam penelitian ini adalah dengan cara melihat rekam medik pasien yang terdiagnosa penyakit diabetes melitus tipe II dengan komplikasi atau tanpa komplikasi di Puskesmas Pasir Sakti.

\section{HASIL DAN PEMBAHASAN}

Penelitian ini menggunakan data rekam medik pasien rawat jalan penderita diabetes mellitus tipe II tahun 2019 di Puskesmas Pasir Sakti. Jumlah sampel yang diambil berdasarkan hasil perhitungan sebanyak 80 sampel dari rekam medis dan resep. Karakteristik pasien dalam penelitian ini didasarkan pada Usia, Jenis kelamin, Diagnosa. 
1. Karakteristik Pasien Berdasarkan Jenis Kelamin dan Usia

Tabel 1 Karakteristik Berdasarkan Jenis Kelamin dan Usia

\begin{tabular}{|c|c|c|c|}
\hline No & $\begin{array}{c}\text { Karakteristik } \\
\text { pasien }\end{array}$ & Jumlah & $\begin{array}{c}\text { Persentase } \\
\%\end{array}$ \\
\hline 1. & $\begin{array}{c}\text { Jenis } \\
\text { kelamin }\end{array}$ & & \\
\hline & Perempuan & 57 & $71 \%$ \\
\hline & Laki-laki & 23 & $29 \%$ \\
\hline 2. & Usia & & \\
\hline & $26-35$ tahun & 0 & $4,30 \%$ \\
\hline & $36-45$ tahun & 8 & $6,45 \%$ \\
\hline & $46-65$ tahun & 65 & $5,38 \%$ \\
\hline & $>65$ tahun & 7 & $4,30 \%$ \\
\hline & Total & 80 & $100 \%$ \\
\hline
\end{tabular}

Berdasarkan tabel di atas menunjukkan bahwa jumlah pasien diabetes melitus tipe 2 berdominan pada jenis kelamin perempuan yakni 57 pasien $(71 \%)$ dibandingkan laki-laki 23 pasien (29\%). Hasil ini sejalan dengan penelitian sebelumnya prevalensi penderita DM Tipe II pada perempuan lebih tinggi dibandingkan pria. Hal ini karena perempuan memiliki Sindrom siklus bulanan yang tidak teratur pasca menopause yang membuat distribusi lemak tubuh menjadi mudah terakumulasi akibat proses hormonal efeknya perempuan lebih berisiko menderita DM tipe II (34). Faktor gaya hidup tidak sehat, obesitas juga dapat mempengaruhi kerja insulin. Jaringan lemak yang menumpuk akan menghambat kerja insulin di jaringan tubuh dan otot sehingga glukosa tidak dapat diangkut kedalam sel dan menimbun di dalam darah yang mengakibatkan hiperglikemia (23).

Berdasarkan usia pasien yang menderita penyakit diabetes melitus tipe II paling banyak pada usia lansia 46-65 tahun yakni 65 pasien (81\%), manula $>65$ tahun 7 pasien $(9 \%)$, usia dewasa akhir $35-45$ tahun 8 pasien $(10 \%)$, sedangkan untuk usia dewasa awal (26-35) tidak ditemukannya data pasien diabetes melitus. Data yang diperoleh sesuai dengan peryataan dari American Diabetes Association (ADA) menyatakan bahwa usia diatas 45 tahun merupakan salah satu faktor risiko terjadinya penyakit Diabetes Melitus tipe II (24). Orang yang mempunyai usia lebih dari 45 tahun dengan pengaturan diet glukosa yang rendah akan mengalami penyusutan selsel beta pankreas. Sel beta pankreas yang tersisa pada umumnya masih aktif, tetapi sekresi insulinnya semakin berkurang (2). Pertambahan usia menjadi faktor resiko tinggi pada penyakit DM tipe II, hal ini berkaitan dengan penurunan fungsi sel pankreas, sekresi insulin, dan resistensi insulin akibat berkurangnya masa otot dan perubahan vascular (32). Kurangnya aktvitas fisik, juga dapat menyebabkan seseorang rentan terhadap berat badan berlebih bahkan obesitas (2).

2. Karakteristik berdasarkan penyakit komplikasi

\begin{tabular}{|c|l|c|c|}
\hline No & Diagnosa & jumlah & $\begin{array}{c}\text { Presentase } \\
\%\end{array}$ \\
\hline 1 & $\begin{array}{l}\text { Dm tipe II } \\
\text { dengan } \\
\text { penyakit } \\
\text { komplikasi }\end{array}$ & 41 & $51,25 \%$ \\
\hline 2 & $\begin{array}{l}\text { Dm tipe II } \\
\text { dengan } \\
\text { penyakit } \\
\text { komplikasi }\end{array}$ & 39 & $48,75 \%$ \\
\hline & Total & 80 & $100 \%$ \\
\hline
\end{tabular}

Tabel diatas menunjukkan pasien DM tipe II dengan penyakit komplikasi sebanyak 41 kasus dengan presentase $51,25 \%$ dan DM tipe 2 tanpa penyakit komplikasi sebanyak 39 kasus dengan persentase $48,75 \%$. Hal ini menunjukkan bahwa pasien DM tipe II di puskesmas pasir sakti banyak yang mengalami penyakit komplikasi. Pasien DM lebih rentan mengalami penyakit komplikasi, karena kadar gula darah yang tidak terkontrol dengan baik dapat menimbulkan berbagai komplikasi. Semakin lama diabetes yang diderita pasien akan semakin besar kemungkinan terjadi komplikasi (23). Hasil ini sejalan dengan penelitian arifin Ibrahim yang menyatakan bahwa $50 \%$ penderita DM tipe II mengalami komplikasi antara lain hipertensi, ulkus (27). 


\section{Penggunaan Obat Diabetes Melitus} Tipe II

Berdasarkan rekam medik, pasien DM tipe II di puskemas pasir sakti mendapatkan obat-obat hipoglikemik oral yang meliputi golongan biguanid, sulfonilurea dan kombinasi keduanya. Gambaran penggunaan obat antidiabetik pada pasien DM tipe II di puskesmas pasir sakti dapat dilihat dibawah ini:

\begin{tabular}{|c|c|c|c|c|}
\hline No. & Golongan & $\begin{array}{l}\text { Obat } \\
\text { yang } \\
\text { diberikan }\end{array}$ & Jumlah & $\begin{array}{l}\text { Present } \\
\text { ase } \%\end{array}$ \\
\hline 1. & Biguanid & $\begin{array}{l}\text { Metformin } \\
500 \mathrm{mg}\end{array}$ & 10 & $12,5 \%$ \\
\hline 2. & sulfonilurea & $\begin{array}{l}\text { Glibencla } \\
\text { mid } 5 \text { mg } \\
\text { Glimepirid } \\
2 \mathrm{mg}\end{array}$ & $\begin{array}{c}32 \\
8\end{array}$ & $\begin{array}{l}40 \% \\
10 \%\end{array}$ \\
\hline 3. & $\begin{array}{l}\text { Kombinasi } \\
\text { golongan } \\
\text { obat }\end{array}$ & $\begin{array}{l}\text { Metformin } \\
\text { +glibencla } \\
\text { mid } \\
\text { Metformin } \\
\text { +glimepiri } \\
\text { d }\end{array}$ & 24 & $\begin{array}{l}30 \% \\
7,5 \%\end{array}$ \\
\hline & \multicolumn{2}{|c|}{ Total } & 80 & $100 \%$ \\
\hline
\end{tabular}

Hasil penelitian menunjukkan gambaran penggunaan obat antidiabetik pada pasien DM tipe II yang digunakan yaitu obat tunggal dan kombinasi. Pada penelitian ini, dari 80 kasus DM tipe II terdapat 50 kasus menggunakan obat tunggal antidiabetik golongan Sulfonilurea (Glibenclamid), dan 30 kasus menggunakan obat kombinasi (Metformin, glibenclamid). Pengobatan lini pertama DM tipe II adalah obat tunggal atau monoterapi manajemen gaya hidup, jika dengan obat tunggal kadar gula darah yang diinginkan tidak tercapai maka perlu ada kombinasi obat dari mekanisme yang berbeda untuk meningkatkan efek hipoglikemia (13).

Hasil penelitian terapi kombinasi yang paling banyak digunakan adalah metformin dan glibenclamid sebanyak 24 kasus. penggunaan obat golongan biguanida dan sulfonilurea bekerja dengan saling menguntungkan dimana golongan sulfonilurea bekerja untuk pemicu sekresi insulin dan golongan biguanida berfungsi untuk meningkatkan sensitivitas insulin. Penelitian Hongdiyanto tahun 2014 menunjukkan kombinasi metformin dan glibenclamid lebih banyak digunakan pada penelitian tersebut (2).

\section{Evaluasi Rasionalitas Pengobatan Dm tipe II}

Evaluasi kerasionalan penggunaan obat antidiabetik dilakukan untuk mengetahui kesesuaian obat antidiabetik yang diberikan dengan standar Perkumpulan Endrokinologi Indonesia PERKENI 2015. Penelitian ini akan dilakukan evaluasi kerasionalan penggunaan obat antidiabetik terhadap tepat indikasi, tepat pemilihan obat, tepat dosis, tepat cara pemberian, tepat interval waktu, kepatuhan pengambilan obat.

\begin{tabular}{|c|l|c|c|c|}
\hline No. & hasil & \multicolumn{2}{|l|}{$\begin{array}{l}\text { Jumlah } \\
\text { pasien }\end{array}$} & \multirow{2}{*}{\begin{tabular}{l} 
Persentase \\
\cline { 3 - 4 }
\end{tabular}} \\
\cline { 3 - 4 } & & tepat & $\begin{array}{l}\text { Tidak } \\
\text { tepat }\end{array}$ & \\
\hline 1. & $\begin{array}{l}\text { Tepat } \\
\text { indikasi }\end{array}$ & 78 & 2 & $97,5 \%$ \\
\hline 2. & $\begin{array}{l}\text { Tepat } \\
\text { pemilinan } \\
\text { obat }\end{array}$ & 79 & 1 & $98,75 \%$ \\
\hline 3. & Tepat dosis & 80 & & $100 \%$ \\
\hline 4. & $\begin{array}{l}\text { Tepat cara } \\
\text { pemberian }\end{array}$ & 80 & & $100 \%$ \\
\hline 5. & $\begin{array}{l}\text { Tepat } \\
\text { interval } \\
\text { waktu }\end{array}$ & 80 & & $100 \%$ \\
\hline 6. & $\begin{array}{l}\text { Kepatuhan } \\
\text { pengambilan } \\
\text { obat }\end{array}$ & 80 & & $100 \%$ \\
\hline
\end{tabular}

\section{Tepat Indikasi}

Hasil penelitian diatas didapat dari rekam medik yang dievaluasi tepat indikasi dilakukan dengan merujuk pada pedoman penatalaksanaan diabetes melitus dari PERKENI 2015. Berdasarkan evaluasi rasionalitas diperoleh sebanyak 78 pengobatan pasien sebesar $(97,5 \%)$ teridentifikasi tepat indikasi dan hanya 2 pasien $(2,5 \%)$ tidak tepat indikasi.

Tepat indikasi merupakan pemberian obat yang sesuai dengan ketepatan 
diagnosis dan keluhan dari pasien. Pada penelitian ini penilaian yang digunakan yaitu pasien awal atau baru didiagnosis menderita diabetes melitus tipe II Menurut PERKENI 2015 diagnosis diabetes melitus ditegakkan atas pemeriksaan glukosa darah. DM dapat ditegakkan melalui tiga cara yang pertama jika keluhan klasik ditemukan maka pemeriksaan glukosa sewaktu $>200 \mathrm{mg} / \mathrm{dl}$ sudah cukup untuk menegakkan diagnosa DM. Kedua pemeriksaan glukosa plasma $\geq 126 \mathrm{mg} / \mathrm{dl}$ dengan adanya keluhan klasik dan yang ketiga adalah tes toleransi glukosa oral (TTGO).

\section{Tepat Pemilihan Obat}

Berdasarkan penelitian hasil ketepatan pemilihan obat sebanyak 79 kasus dengan persentase $98,75 \%$ dan tidak tepat obat sebanyak 1 kasus dengan presentase $1,25 \%$. Pada penderita DM komplikasi hipertensi yaitu darah yang terlalu kental akibat tingginya kadar gula dapat menyebabkan penyempitan pada pembuluh darah yang mengakibatkan otot jantung menjadi lemah (37). Menurut American Diabetes Association (ADA) pengobatan DM komplikasi hipertensi diberikan obat golongan ACE dan ARBs untuk mencapai tekanan darah $130 / 80 \mathrm{mmHg}$ yang harus dicapai pasien DM komplikasi hipertensi. Ketepatan pemilihan obat adalah kesesuaian pemilihan suatu obat diantara beberapa jenis obat yang mempunyai efek terapi yang sesuai untuk penyakit DM tipe II, berdasarkan standar PERKENI 2015. Obat yang diberikan harus terbukti manfaat dan keamanannya, baik penggunaan obat tunggal maupun kombinasi dua obat antidiabetik yang digunakan secara bersamaan dapat memberikan manfaat yang lebih dalam mengontrol kadar gula darah.

\section{Tepat Dosis}

Berdasarkan penelitian hasil ketepatan dosis dikatakan tepat dosis sebanyak 80 kasus dengan persentase $100 \%$. Hasil dari penelitian ini yaitu ketepatan dosis pada pasien DM tipe II dikatakan tepat dosis berdasarkan diagnosa dan standar PERKENI 2015. Dosis metformin yang digunakan untuk pasien DM tipe 2 sebesar $500 \mathrm{mg}$, glibenklamid sebesar $5 \mathrm{mg}$ dan glimepirid sebesar 2 mg. Pengobatan dikatakan tepat dosis apabila dosis pemberian antidiabetik sesuai dengan standar PERKENI 2015. Dosis yang sesuai juga dilihat dari keadaan fungsi organ tubuh pasien, misalnya dalam keadaan fungsi ginjal yang menurun pemberian dosis terapi akan terpengaruh, bahkan jika fungsi ginjal telah memburuk pemberian antidiabetik dapat diberikan secara parenteral untuk menghindari keparahan penyakit pasien.

\section{Tepat cara pemberian}

Berdasarkan penelitian hasil ketepatan cara pemberian obat sebanyak 80 kasus dengan persentase $100 \%$ dikatakan tepat cara pemberian obat. Pemberian obat antidiabetik oral dapat diberiakan sebelum makan, bersama makanan, atau sesudah makan. Pemberian obat ini akan mempengaruhi efektivitas kerja dari obat tersebut sehingga dapat mempengaruhi jumlah obat yang masuk kedalam tubuh.

\section{Tepat Interval waktu}

Berdasarkan penelitian hasil ketepatan interval waktu dikatakan $100 \%$ tepat karena sesuai dengan standar PERKENI 2015. Penggunaan glibenklamid 1-2 kali sehari maksimal $10 \mathrm{mg}$ per hari karena waktu paruhnya sekitar 3-5 jam, tetapi efek hipoglikemiknya dapat berlangsung selama 12-24 jam. Sementara itu, penggunaan metformin 1-3 kali sehari maksimal $500 \mathrm{mg}$ per hari (13). Berdasarkan hasil penelitian dipuskesmas pasir sakti didapat bahwa pemberian Glibenclamid atau glimepirid 1 kali sehari dan metformin 2 kali sehari.

Diberikannya obat golongan biguanid atau metformin karena obat tersebut 
bekerja mengurangi produksi gula pada hati sedangkan untuk golongan sulfonilurea berfungsi meningkatkan sekresi insulin (25). Metformin bisa digunakan bersama atau sesudah makan, Sedangkan untuk glibenklamid dapat digunakan 15-30 menit sebelum makan untuk menghindari efek hipoglikemi (17). Interval waktu penggunaan obat merupakan hal yang penting dalam penggunaan suatu obat sebab dapat mempengaruhi lama efektivitas obat tersebut, yakni selisih waktu antara waktu mula kerja dan waktu yang diperlukan obat untuk turun kembali ke konsentrasi minimum. Interval penggunaan obat yang tidak sesuai akan menyebabkan frekuensi penggunaan obat yang tidak sesuai (25).

\section{Kepatuhan pengambilan obat}

Berdasarkan penelitian kepatuhan pengambilan obat dikatakan $100 \%$ tepat karena, dari data rekam medik menunjukan bahwa pasien diabetes melitus diberikan peresepan dalam jangka waktu 1 bulan. Pemberian obat OAD harus diminum secara rutin dan tidak boleh putus karena pemberian obat yang terlalu singkat atau terlalu lama dari yang seharusnya akan berpengaruh terhadap hasil pengobatan (35).

\section{KESIMPULAN DAN SARAN}

\section{KESIMPULAN}

Berdasarkan penelitian yang dilakukan terhadap penggunaan antidiabetik pasien rawat jalan diabetes melitus tipe II di puskesmas pasir sakti tahun 2019 dapat disimpulkan:

Karakteristik berdasarkan jenis kelamin pasien diabetes melitus tipe II paling banyak yaitu pada jenis kelamin perempuan sebanyak 57 pasien $(71,25 \%)$ dan laki-laki sebanyak 23 pasien (28,75\%). Berdasarkan usia paling banyak pada usia lansia 46-65 tahun sebanyak 65 pasien $(81,25 \%)$, dan manula $>65$ tahun sebanyak 7 pasien (8,75\%), dan dewasa akhir 35-45 tahun sebanyak 8 pasien (10\%).

Pengobatan DM tipe II dipuskesmas pasir sakti yang mendapatkan terapi rasional sebanyak 77 pasien dengan presentasi $96,25 \%$, sedangkan untuk terapi tidak rasional sebanyak 3 pasien dengan persentase $3,75 \%$.

Penggunaan obat antidiabetik yang digunakan pada pasien diabetes melitus tipe II dipuskesmas pasir sakti periode 2019 berdasarkan PERKENI 2015 dilihat dari kriteria tepat indikasi sebesar $97,5 \%$, tepat obat sebesar $98,75 \%$, tepat dosis, tepat cara pemberian, tepat interval waktu, dan kepatuhan pengambilan obat sebesar $100 \%$.

\section{SARAN}

Saran yang dapat disampaikan berdasarkan hasil penelitian yaitu:

Bagi puskesmas diperlukan upaya peningkatan dalam hal kelengkapan pencatatan rekam medik.

Bagi peneliti selanjutnya dapat dilakukan penelitian lebih lanjut di puskesmas lain dengan jumlah sampel yang lebih banyak agar semakin memperkuat hasil penelitiannya dalam evaluasi rasionalitas pengobatan pada kasus yang sama.

\section{DAFTAR PUSTAKA}

[1] American Diabetes Assosiation, Standart Of Medical Care in Diabetes. USA: Diabetes Care, 2016.

[2] H. Arnold Hongdiyanto, Paulina, Evaluasi Kerasionalan Pengobatan Diabetes Melitus Tipe 2 pada Pasien Rawat Inap Di RSUP Prof .Dr.R.D Kandau Manado. Manado: Jurnal Ilmiah Farmasi, 2014.

[3] Kementrian Kesehatan RI, Hasil Utama Riskesdas Tentang 
Prevalensi Diabetes Mellitus di Indonesia. Jakarta: Kementerian Kesehatan Republik Indonesia, 2018.

[4] Dinas Kesehatan. Profil Kesehatan Provinsi Lampung. Lampung: Dinas Kesehatan Provinsi Lampung. 2015.

[5] Departemen Kesehatan republik Indonesia, Pharmaceutical Care Untuk penyakit Diabetes Melitus. Jakarta: Departemen Kesehatan Republik Indonesia, 2005.

[6] A. P. dan H. Hongdiyanto, Evaluasi Kerasionalan Pengobatan Diabetes Melitus Tipe 2 pada Pasien Rawat Inap di RSUP Prof. Manado. Manado: UNSRAT, 2013.

[7] World Health Organization, Medicines Use In Primary Care in Developing and Transitional Countries. Geneva: World Health Organization, 2009.

[8] Irawan D. Prevalensi dan Faktor Risiko Kejadian Diabetes Melitus Tipe 2 di Daerah Urban Indonesia. 2010 (Analisa Data Sekunder Riskesdas 2007).

[9] ADA (American Diabetes Association). Standards of Medical Care in Diabetes. Volume 37, Alexandria: 2014. p. 516.

[10] Sri Rahayu Yulianti. Propil Pengobatan Pasien Diabetes Melitus Tipe 2 Di Instalasi Rawat Inap RSUD Undata Palu. Prodi Farmasi UNTAD: 2014

[11] Tri Shintya Dewi. Evaluasi Rasionalitas Penggunaan Antidiabetik Pada Pasien Rawat Inap Diabetes Melitus Tipe 2 di RSUD Karang Anyar. Surakarta: 2015.

[12] Arifin ibrahim. Evaluasi Kerasionalan Pengobatan Diabetes Mellitus Tipe
2 pada Pasien Rawat Inap di Rumah Sakit Bhakti Wira Tamtama Semarang Universitas Wahid Hasyim, Semarang. 2012.

[13] Perkeni, Konsensus Pengelolaan dan Pencegahan Diabetes Mellitus Tipe 2 di Indonesia. jakarta: Perkumpulan Endokrinologi Indonesia, 2015.

[14] Astri meirinawati Evaluasi Penatalaksanaan Terapi Diabetes Melitus Komlpikasi Hipertensi Rawat Inap Rumah Sakit panti Rapih Yogyakarta: 2015

[15] Khudz Nafi'ah, I Nyoman Wijaya. Profil Kepatuhan Pasien Puskesmas Pucang Sewu Surabaya Dalam Penggunaan Antidiabetik Oral. Jurnal Farmasi Komunitas Vol. 2, No. 1. 2015

[16] Perkeni, Konsesus Pengendalian dan Pencegahan DM tipe 2 di Indonesia. jakarta: Perkumpulan Endokrinologi Indonesia, 2011

[17] Departemen Kesehatan RI. Pedoman Pengendalian Diabetes Melitus dan Penyakit Metabolik. Direktorat Jenderal Pengendalian Penyakit dan Penyehatan Lingkungan Departeman Kesehatan RI. 2010. 


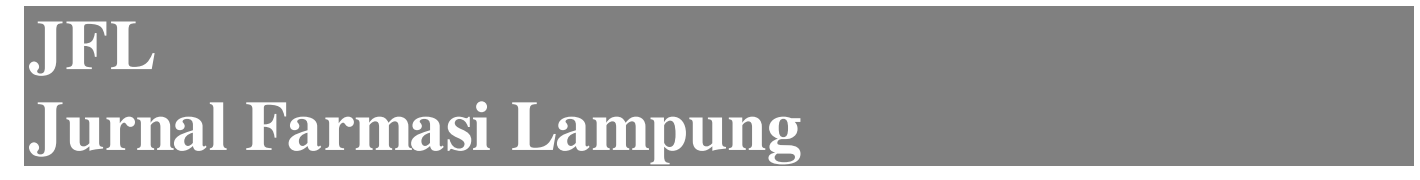

